\title{
Bohdan Dziemidok, Teoretyczne i praktyczne kłopoty z wartościami i wartościowaniem. Szkice z aksjologii stosowanej, Wydawnictwo: słowo/obraz terytoria, Gdańsk 2013, ss. 292
}

DOI: http://dx.doi.org/10.12775/RF.2014.039

W polskiej filozofii dwudziestego wieku obok silnego trendu analitycznego, stosującego radykalnie wymagania i metody analizy logicznej do każdej ważnej kwestii filozoficznej, uprawiano z pożytkiem filozofię wartości i aplikowano ją głównie do etyki i estetyki. Pokolenie ojców fundatorów polskiej aksjologii stanowili Władysław Tatarkiewicz, Florian Znaniecki, Henryk Elzenberg, Tadeusz Czeżowski, Roman Ingarden, Tadeusz Kotarbiński, którzy w różny sposób i w różnym zakresie uformowali myśl aksjologiczną międzywojnia i drugiej połowy wieku, rozwijaną potem $\mathrm{w}$ różnych ośrodkach filozoficznych w Polsce. Charakterystyczną cechą tej twórczości była koncentracja na fundamentalnych problemach aksjologii, czyli na zagadnieniach wchodzących w obszar ogólnej teorii wartości, ale nie brakowało również badań szczegółowych, $\mathrm{w}$ istocie aksjologicznych, penetrujących twórcze przejawianie się i przeżywanie wartości w świecie moralności lub kultury estetycznej. Nie wszyscy jednak zajmujący się poszczególnymi obszarami szeroko rozumianej humanistyki nawiązywali do porządku pojęciowego, nad którym pracowała ogólna aksjologia. Niektórym, jak na przykład Romanowi Ingardenowi, wydawała się ona nawet zbędna.

Bohdan Dziemidok należy do tych badaczy świata wartości, którym fundamentalne kwestie aksjologiczne nie są wprawdzie obce, ale który przyswoiwszy je sobie, dobrze czuje się $\mathrm{w}$ analizie problemów etyki czy estetyki ujmowanych w horyzoncie ich specyfiki, semantyki, sporów teoretycznych. Książka nosi w tytule zapowiedź podjęcia teoretycznych i praktycznych kłopotów z wartościami i wartościowaniem, ale niech to nas nie zmyli, bo nie o czysta, ogólną teorię wartości, czyli o odpowiedź na pytanie: czym są i jakie są wartości? - tu chodzi, ale o zrozumienie wybranych do analizy wartości, przysparzających w codziennym życiu najwięcej problemów interpretacyjnych i decyzyjnych. Ich wymiar teoretyczny tkwi w czym innym niż ustalanie statusu wartości struk- 
turach bytu i przedmiotów poznania. W podtytule książki pojawia się rzadko spotykany w polskiej literaturze filozoficznej termin aksjologia stosowana, sugerujący jakiś jej związek z aksjologią teoretyczna, rodzaj zależności. Może lepiej byłoby użyć nazwy aksjologia szczegółowa, by potwierdzić podtytułem wstępną zapowiedź Autora, że nie będzie się zajmował kwestiami związanymi z pytaniem: co to jest wartość (czyli subiektywnościa/obiektywnością wartości, ich względnościa/absolutnością, stosunkiem sądów wartościujących do sądów orzekających, logiczną kwalifikowalnością ocen). Jaki jest pogląd Autora na ontologiczny i epistemologiczny status wartości i ich najogólniejszy porządek, tego we wprowadzeniu do aksjologii stosowanej nie ma. Można mieć jednak nadzieję, że czytelnik o bardziej wymagających oczekiwaniach teoretycznych znajdzie odpowiedź na pytania ogólnoteoretyczne $\mathrm{w}$ toku lektury. W każdym razie, ten kłopot z wartościami i wartościowaniem został tu podjęty, i właściwie, choć książka dałaby tym samym pełny, wielowarstwowy obraz kłopotów z wartościami - poczynając od tego zasadniczego kłopotu, jakim jest pytanie o istnienie i poznanie wartości - trudno się dziwić Profesorowi Dziemidokowi, że te zagadnienia pominął, bo cel i materia tomu są zgoła inne.

Książka opiera się na tekstach wcześniej publikowanych, często okazjonalnie, a jej celem i przedmiotem jest zapośredniczona $w$ teorii analiza wartości i problemów o znaczącym wymiarze praktycznym. A są nimi: wolność, szczęście i tożsamość narodowa. Do tej triady Autor dodaje niezwykle ważną społecznie egzystencjalno-aksjologiczną analizę starości. Osobnym i znowuż aktualnym zagadnieniem aksjologii stosowanej są etyczne dylematy polityków i obywateli wybierających polityków, problemy etyki nauczycielskiej, a także wartościowania sztuki popularnej. Interesujące, że zbiór szkiców kończy tekst poświęcony aksjologii Władysława Tatarkiewicza, filozofa, który chyba najbardziej wpłynął na poglądy Autora swoimi badaniami z zakresu teorii wartości estetycznych i teorii szczęścia. Także niezwykle komunikatywny język całej książki jest echem, odpowiedzią na głoszoną kiedyś przez Tatarkiewicza zasadę maksymalnej troski o to, aby o rzeczach trudnych i ważnych pisać jak najprościej, jasno, zrozumiale.

Rozdział pierwszy, Teoretyczne i praktyczne kłopoty z wolnościa, łączy cechy elementarnego wykładu podstaw filozofii i psychologii wolności z refleksją nad złożonym charakterem wolności. Rozważania Autora rozciągają się między relacją wolności do determinizmu a wolnością w polu odpowiedzialności, także odpowiedzialności środowisk zawodowych. Trudno tu się z czymś nie zgodzić, a zwłaszcza z tym, że wolność jest nie tylko ciężarem dla człowieka, bowiem jest także źródłem radości.

Pytaniem o to: Jak żyć? Jak żyć, żeby być zadowolonym z życia? zajmuje się Autor w rozdziale Teoretyczne i praktyczne kłopoty ze szczęściem. Punktem odniesienia dla rozważań są pojęcie i teoria szczęścia 
Władysława Tatarkiewicza zawarta w głośnym jego traktacie O szczęściu (1947). Wartość filozoficzna tego rozdziału polega przede wszystkim na tym, że Dziemidok aktualizuje ten traktat odwołaniami do współczesnych badań psychologicznych oraz wypowiedziami autorytetów filozoficznych i psychologicznych na temat pojęcia szczęścia i jego osiągalności. Dopuszczeni zostali więc tu pokrótce do głosu zarówno sceptycy (U. Eco, L. Kołakowski, B. Skarga), jak i myśliciele, którzy pozostają otwarci na badanie możliwości ludzkiego szczęścia, kładąc nacisk na społeczno-kulturowe konteksty rozumienia i praktykowania szczęścia (Z. Bauman), także na witalne, społeczne i psychologiczne uwarunkowania szczęścia, i może bardziej - zapobiegania nieszczęściu (A. Czapiński). Istotnym składnikiem tej aktualizacji jest wreszcie zwrócenie uwagi na psychologię pozytywną (M. Seligman), na której opierają się liczne poradniki szczęścia. Kiedyś była to domena filozofów, dziś psychologów pozytywnych.

Uporawszy się z krótkim opisem głośniejszych badań w zakresie teorii szczęścia, Dziemidok przystępuje do sformułowania własnych uwag praktycznych. Ich podstawą teoretyczną czyni zarówno definicyjne oraz teoretyczne ustalenia Tatarkiewicza, jak i B. Russella książkę Podbój szczęścia (1930). O ile Tatarkiewiczowi przypisuje Dziemidok brak rozwiniętej teorii osiągalności szczęścia, to wiele trafnych spostrzeżeń teoretycznych i praktycznych prowadzących do poczucia szczęścia znajduje u Russella, nazywając go prekursorem psychologii pozytywnej. Nawiązując do porad Seligmana (Optymizmu można się nauczyć, 1990) oraz innych poradników, formułuje listę 15 warunków szczęścia, które mają tyleż podłoże teoretyczne $\mathrm{w}$ antropologii i biotechnice, co i opierają się o zdroworozsądkowe doświadczenie warunków dobrego życia i współżycia promieniującego zadowoleniem. To bardzo cenne, mądre i dowcipne zestawienie najważniejszych czynników szczęścia, które może komuś się wydawać nadmiernie ironiczne, ale miejscami żartobliwa konwencja tego tekstu ma swoje potwierdzenie w umieszczeniu na 15 pozycji listy porad zaczynających się od stosunku do pracy, także roli humoru w życiu. Ideą przewodnią tego szkicu jest jednak przekonanie, że nie ma doskonałej recepcji na życie szczęśliwe, utwierdzając czytelnika w przekonaniu, że problematyka szczęścia wprawdzie bardziej dziś absorbuje uwagę psychologów pozytywnych niż filozofów, ale tak bynajmniej być nie musi.

Kolejny kluczowy aksjologiczny rozdział dotyczy wartości wspólnotowych, a więc podstaw etyki społecznej. Jego tytuł wpisuje się $\mathrm{w}$ schemat poprzednich i dotyczy teoretycznych oraz praktycznych kłopotów z tożsamością narodową. Kluczowym zagadnieniem teoretycznym jest potrzeba samoidentyfikacji w relacji do innych i konstruowanie wizerunku własnego w stosunku do innych, obcych. W dyskusję tego zagadnienia na przykładzie tożsamości narodowej wprzęgnął 
Autor najwybitniejszych polskich socjologów i nie tylko polskich. Dla nas interesująca jest treść aksjologiczna tej tożsamości, stanowiąca z jednej strony źródło orientacji na istotne w życiu i stosunkach z innymi wartości. Do wieloaspektowego opisu teorii wspólnoty, jej pozytywnych i negatywnych stron, Autor włącza swoje doświadczenia z 11 lat spędzonych $\mathrm{w}$ wielu naukowych ośrodkach zagranicznych i z tej pozycji również rozważa problemy współczesnych lęków czy prognoz wieszczących roztopienie się poczucia tożsamości narodowej w kulturze globalistycznej, źródła nacjonalizmów i różnego rodzaju ksenofobii. Trudno nie docenić poprzednich rozdziałów, ale ten ma wyjątkowe znaczenie dla wychowania patriotycznego i obywatelskiego.

Esej poświęcony starości zawiera rozważania wokół odpowiedzi na pytanie nawiązujące do tytułu książki Esther Vilar Starość jest piękna (polskie wydanie 2008) i prowokująca do pytań o to: „czy starość jest lub może być piękna, mądra, dobra i szczęśliwa"? W eseju niepozbawionym interesujących konstatacji i nawet autoironii dochodzi Autor do wniosku, że starość może być piękna, bo może być wypełniona wartościami, które przyswoił sobie człowiek we wcześniejszych fazach życia. Do starości trzeba się przygotować, nie tylko materialnie, ale i psychicznie. Dolegliwości wieku starczego (cierpienie, zmęczenie i bezczynność) nie są wprawdzie, jego zdaniem, do uniknięcia, ale można ich konsekwencje ograniczyć, starając się nie dopuścić do uskrajnienia zalet, które mogą stać się wadami (oszczędność staje się skąpstwem), a zintensyfikowane wady charakteru stają się nieznośne. To piękny, mądry esej, wart polecenia nie tylko ludziom starszym, rozmyślającym nad kryteriami oceny swojego życia, ale także młodym, budującym fundamenty nieuniknionej starości. Polecam ten tekst nawet, może zwłaszcza młodzieży studiującej, nie tylko filozofię, aby uczyć kultury obcowania z przemijaniem własnym i cudzym.

Kolejny esej zatytułowany Etyczne dylematy polityków dotyczy nie tylko polityków. W pewnej mierze rozważane są w nim także podstawowe dylematy etyki obywatelskiej związane z oceną polityków i wyborami, jakie obywatel powinien dokonać, by wziąć udział w ukonstytuowaniu swojej reprezentacji we władzach państwa. Główne dylematy sprowadzone zostały do wyboru między skutecznością a moralnością polityków, co jednak nie znaczy, że pragmatyzm polityczny i uczciwość polityczna zawsze wykluczają się w tej dziedzinie. Lista dylematów sporządzona została z dużym wyczuciem realizmu i aktualności. Autor o niczym tu nie rozstrzyga, nie podaje gotowych rozwiązań, nie moralizuje, lecz opisuje tylko ramy sporu, jego kontrastowe pozycje, co stanowi materiał do dość kompletnego szkicu dyskusji podstawowych moralnych i etycznych problemów współczesnej polityki.

Do etyki nauczyciela akademickiego odnosi się Profesor Dziemidok w następnym krótkim eseju. Najpierw zajmuje stanowisko 
w trwającym już lata sporze o status etyki zawodowej, o jej potrzebę i sensowność w kontekście etyki ogólnej. Nie wnikając we wszystkie aspekty kontrowersji, przyjmuje, że etyka zawodowa jest potrzebna, jako że maksymalizuje ona wymagania etyczne w zawodzie względem niektórych $\mathrm{z}$ nich, a minimalizuje względem innych. Zasady etyki nauczyciela akademickiego przedstawione zostały $\mathrm{w}$ zarysie $\mathrm{z}$ podziałem na te, które wiążą się z prowadzeniem badań i ich rozpowszechnianiem oraz na dotyczące stosunku do obowiązków dydaktycznych, a ponadto także postaw wychowawczych. Wszystkie zasady mają swój osobowy i międzyosobowy wymiar, co na zakończenie zostaje sprowadzone do dwu uniwersalnych cnót: godności i uczciwości nauczyciela akademickiego.

Wartości kultury masowej i sztuki popularnej to kolejny temat, któremu poświęcona została refleksja nad ich wartościowaniem. To temat sporny, odzwierciedlający dość szczególną sytuację w kulturze o złożonych relacjach między twórcami a odbiorcami zarówno sztuki elitarnej, jak i sztuki popularnej, między kulturą wysoką a kulturą masowa, temat związany z różną oceną ich wartości, czyli z jednej strony z uznawaniem sztuki popularnej za mało wartościowa, a z drugiej strony $z$ traktowaniem sztuki elitarnej jako niezrozumiałej i oderwanej od potrzeb zwykłych ludzi. Oba stanowiska mają swoich intelektualnych rzeczników i oba Dziemidok omawia, by w kluczowym momencie poddać analizie argumenty w sprawie różnych funkcji i wartości sztuki popularnej. Wynik tej analizy skłania Autora do wniosku, że sztuka popularna zarówno wzbogaca wiedzę człowieka o świecie, jak i tworzy lub utrwala stereotypy nie zawsze adekwatne do rzeczywistości, ale bodajże szczególnie ważna jest tu ta wiedza, która wnika $\mathrm{w}$ indywidualne ludzkie przeżycia i losy, wymykające się schematyzmowi opisu naukowego. Sztuka sprzyja też zachowaniu równowagi psychicznej człowieka, a także zaspakajaniu wielu potrzeb psychicznych człowieka, od potrzeby rekreacji poczynając, a na potrzebie rozładowania bolesnych napięć kończąc. Wreszcie sztuka może wpływać na kształtowanie postaw moralno-obyczajowych jej odbiorców, może promować ideały, demaskować zło, tworzyć i wzmacniać więzi między jej odbiorcami na bazie wspólnych wartości. Sztuka może także demoralizować, dostarczać złych wzorów, wprowadzać odbiorców w świat fikcyjny, w którym więzi międzyludzkie ulegają erozji. Autor zajmuje się nieco dokładniej problemem obecności erotyzmu i graniczącej z nim pornografii w sztuce, ich związkiem ze zmianami obyczajowymi w społeczeństwie. To bardzo interesujący, wyrastający z kompetencji Profesora jako estetyka, wątek.

Ostatni esej poświęcony został osobie i twórczości aksjologicznej i etycznej Władysława Tatarkiewicza, którego Bohdan Dziemidok nazywa swoim guru. Panowie spotkali się w latach 1966/1967 w stano- 
wym Uniwersytecie Kalifornijskim w Berkeley, w okresie ożywienia ruchów młodzieżowych, studenckich form kontestowania tradycji kulturowej i manifestowania wyzwolenia z jej gorsetu. Profesor Dziemidok opisuje tu w szczególności relacje spokój i elegancję, z jaką wykłady Tatarkiewicza o klasycznej estetyce zderzały się z różnorodnością kulturową środowiska słuchaczy, z ich wyluzowaną obyczajowością i nacechowane były wzajemnym zaciekawieniem i szacunkiem. To bodajże najlepsza i niezwykle interesująca charakterystyka 81-letnego wtedy Uczonego, "przedwojennego dżentelmena” stykającego się ze środowiskiem, w którym idee i praktyki hipisowskie były silnie reprezentowane. $W$ całości ten esej jest zarazem obrazem człowieka słusznie szczęśliwego, praktykującego teorię szczęścia, której poświęcił jeden z najpiękniejszych traktatów filozoficznych w literaturze polskiej, wspomniany już wyżej traktat $O$ szczęściu.

Czytelnik może tu również zapoznać się z dość przystępnym szkicem aksjologii Tatarkiewicza, a szczególnie z interpretacją świata wartości estetycznych, $\mathrm{z}$ akcentem położnym na pluralistyczną interpretacji sztuki i pluralizm teorii estetycznych. Bohdan Dziemidok w tym szkicu, jak i we wcześniej opisanych wymiarach świata wartości i wartościowań ludzkich zdaje się obierać za punkt wyjścia rozważań aksjologię szczegółowa, tu etykę i estetykę. W moim odczytaniu tych rozważań dostrzegam pewne niuanse w niedocenieniu ważności ogólnoaksjologicznego klucza rozumienia i porządkowania całej sfery wartości. Z perspektywy szczegółowych aksjologii Autor książki słusznie zauważa pewien stopień względności i następnie relacyjności między tym, co subiektywne a obiektywne w estetyce oraz w teorii szczęścia. Mam jednak wątpliwości, czy to jest odejście od międzywojennego absolutyzmu i obiektywizmu aksjologicznego. Z moich studiów nad aksjologią Tatarkiewicza wynika, że trzeba odróżniać ogólnoaksjologiczną bezwzględność i obiektywność pewnych kluczowych wartości (tworzących aksjomatyczne „prawdy pierwsze” wobec świata dóbr), jak piękno czy szczęście, od ich względności i relacyjnej subiektywności w sposobie ich konkretnego przejawiania się w życiu i sztuce. Z tego, że szczęście czy piękno, a także reguły słuszności charakteryzują się pewnym stopniem relatywizacji i zawierają współczynnik subiektywności (są relacyjne) nie wynika, że ten status ontyczno-aksjologiczny przenosi się na ich status ogólno-aksjologiczny. Szlachetność, szczęście czy piękno - mają wartość bezwzględną i obiektywną - jakkolwiek ich konkretne przejawy zawierają element swoistej względności i subiektywności ${ }^{1}$. Tatarkiewicz, w miarę jak uszczegółowiał swoje badania aksjologiczne i skupiał się na tym ich wymiarze, zdawał się traktować je

1 Pisałem o tym, w: R. Wiśniewski, Dobro, moralność, szczęście i piękno. Studium aksjologii Władystawa Tatarkiewicza, Epigram, Bydgoszcz 2013. 
jako w jakimś sensie względne i relacyjne (subiektywno-obiektywne), ale to nie unieważnia aksjomatyki tych wartości ujmowanych jako bezwzględne i obiektywne, o czym miałem $\mathrm{w}$ latach siedemdziesiątych okazję rozmawiać z Profesorem, i potwierdzał to. Nie dziwię się jednak Profesorowi Dziemidokowi, że dostrzega tu zwrot w stronę relatywizmu i subiektywizmu, skoro sam Tatarkiewicz czasem brał w nawias swoje wcześniejsze założenia.

Wróćmy w tym miejscu do punktu wyjścia tej recenzji, do pytania o kłopot naczelny z wartościami, który należy do ogólnej teorii wartości, a także w związku z tym do teoretycznej warstwy aksjologii szczegółowych. Studium aksjologii Tatarkiewicza pokazuje, że wgląd w świat wartości, w jego problemy, jest dwustronny. Z jednej strony analizuje się wartościowość jako swego rodzaju jakość czy sposób istnienia przedmiotów uważanych za dobre, i jeśli coś się ustali pozytywnego $\mathrm{w}$ sprawie istnienia i poznania wartości, to można $\mathrm{w}$ tym ogólnym trybie porządkować świat wartości. Tak powstaje ogólna teoria i ogólny system wartości. Ale z drugiej strony można analizować wartości tak, jak są nam dane, zróżnicowane w swej treści, powiązaniach i opozycjach, i dopiero na tej podstawie pytać o ich status poznawczy i aksjologiczny. Ten sposób badania wartości, należący w istocie do aksjologii szczegółowej czy szczególnej, dominuje w książce. Nie nazwałbym tego aksjologią stosowana, bo trzeba by najpierw ustalić jej związek z aksjologią teoretyczna, co się tu stosuje. Chyba, że chodzi o różne obszary stosowanej aksjologii szczegółowej, a szczegółowa zawiera własną, niezależną od ogólnej, warstwę teoretyczną. Tak czy inaczej, tytuł i podtytuł książki daje do myślenia w sprawie uporządkowanego posługiwania się terminem aksjologia w różnych kontekstach pragmatycznych. Zaintrygowany tą nazwą przyjmuję, że chodzi tu o aksjologię praktyczna, związaną z życiem, z realnymi problemami ludzi.

Książka Profesora Dziemidoka ma przede wszystkim liczne zalety. Pierwszą zaletą książki, obok wartości poznawczych wprowadzających w świat głównych sporów aksjologicznych współczesnego życia rejestrowanych przez filozofów, socjologów i psychologów, jest jej ton osobisty, wyrażający doświadczenie myśliciela i nauczyciela akademickiego, ofiarującego czytelnikowi swoje przemyślenia. Nie bez znaczenia jest też doświadczenie wyniesione z długoletnich wyjazdów zagranicznych oraz z pracy w różnych ośrodkach naukowych w kraju. Książka ma bez wątpienia charakter mądrościowy, eseistyczny, jest dobrym przykładem popularyzatorskiej misji filozofii jako podstawy mądrego, wolnego, wrażliwego moralnie, społecznie i estetycznie życia, przygotowującego do pogodnej starości i zasłużonego poczucia szczęścia. Z całą pewnością należy polecać ją nauczycielom, wykorzystywać w szkole średniej i wyższej. Środowisko akademickie zna Profesora Dziemidoka jako świetnego dydaktyka, podającego rzetelną 
wiedzę w kontekście refleksji nad urokami życia i przykrościami, jakie mogą nas w nim spotkać. Co ważne, nie ma w tej książce nic wyniosłego, nie ma nadętego moralizmu, owszem nie brakuje w niej natomiast mniej lub bardziej jawnej i urokliwej, dowcipnej autoironii człowieka lubiącego życie i ludzi, ceniącego sobie dobrą komunikację z nimi.

Ryszard Wiśniezwski 